\title{
Familial Mediterranean fever (FMF) and Sjögren's syndrome: A case responding to azathioprine treatment
}

\section{Ailevi Akdeniz Ateşi (AAA) ve Sjögren Sendromu (SS): Azatioprin tedavisine yanıt veren bir olgu}

*Ali Şahin ${ }^{1}$, Şükran Erten ${ }^{2}$, Mehtap Şahin ${ }^{3}$, Sezen Koçarslan ${ }^{4}$, Ahmet Kerim Türesin

${ }^{1}$ Department of Rheumatology, Cumhuriyet University School of Medicine, Sivas, Turkey

${ }^{2}$ Department of Rheumatology, Yıldırım Beyazit University School of Medicine, Atatürk Education and Research Hospital, Ankara, Turkey

${ }^{3}$ Department of Biochemistry, Cumhuriyet University School of Medicine, Sivas, Turkey

${ }^{4}$ Department of Medical Pathology, Harran University School of Medicine, Şanlıurfa, Turkey

${ }^{5}$ Department of Internal Medicine, Cumhuriyet University School of Medicine, Sivas, Turkey

Corresponding author: Dr. Ahmet Kerim Üresin, İç Hastalıkları Anabilim Dalı, Cumhuriyet Üniversitesi Tıp Fakültesi, TR-58140, Sivas, Turkey.

E-mail: drahmetkerim@hotmail.com

Received/Accepted: April 25, 2014/September 03, 2015

Conflict of interest: There is not a conflict of interest.

\section{SUMMARY}

Sjögren's syndrome (SS) is a chronic, autoimmune, systemic exocrinopathy and extraglandular manifestations can be seen in the course of the disease. Vasculitic skin lesions can rarely be seen in patients. Familial Mediterranean fever (FMF) is a familial, recurrent, autoinflammatory disease which is seen mostly in young people and characterized by self-limiting attacks responding to colchicine treatment. However, resistance to colchicine might be seen in some cases. Coexistence of FMF and SS is rare and the use of azathioprine (AZA) for the treatment of resistant FMF is yet controversial. Herein, we aim to share the post-treatment positive findings of a colchicine-resistant patient diagnosed with FMF and SS comorbiding vasculitis treated with AZA.

Keywords: azathioprine, resistant-FMF, Sjögren's syndrome, vasculitis

ÖZET

Sjögren sendromu (SS), kronik, otoimmün, sistemik ekzokrinopatidir ve ekstarglandüler bulgular hastalığın seyrinde görülebilir. Bazı hastalarda nadirende olsa vaskülitik cilt lezyonları görülebilmektedir. Ailevi Akdeniz ateşi (AAA), ailevi otoinflamatuvar bir hastalık olup daha çok genç yaştaki bireylerde tekrarlayan, kendi kendini sınırlayan ataklarla karakterize ve tedavisinde daha çok kolşisin ile yanıt alınan bir hastalıktır. Fakat bazı vakalarda kolşisine direnç olmaktadır. AAA ve SS birlikteği nadir olup özellikle dirençli-AAA tedavisinde azatioprin (AZA) kullanımı da henüz tartışmalıdır. Biz burada AAA ve vaskülitin eşlik ettiği SS'lu AZA ile tedavi edilen kolşisin dirençli hastada ortaya çıkan an lamlı yanıtı sunmak istedik.

Anahtar sözcülkler: Azatiyoprin, dirençli-AAA, Sjögren sendromu, vaskülit

\section{INTRODUCTION}

Sjögren's syndrome (SS) is an autoimmune, chronic and systemic disease characterized by involvement of exocrine glands especially lacrimal and salivary glands. It is a chronic autoimmune disease characterized by lymphocytic infiltration causing exocrinopathy and extraglandular findings can be seen in the course of the disease ${ }^{1}$. Vasculitic skin lesions can be detected in approximately $15 \%$ of the patients. Also hypocomplementemic urticarial vasculitis, medium-sized vessel vasculitis (i.e polyarteritis nodosa) and smallvessel vasculitis have been reported. Vas- 
culitis is common especially in patients with autoantibody-positivity and systemic findings $^{2,}$ 3. FMF is a familial, recurrent autoinflammatory disease mostly seen in young people and characterized by selflimiting attacks including fever, arthritis, serositis and most of the time responding to colchicine treatment ${ }^{4}$. However, colchicine resistance can be seen in about 10$15 \%$ of the cases. The vasculitis such as polyarteritis nodosa (PAN), HenochSchönlein purpura (HSP), and vasculiticskin lesions can be seen during the illness in some cases. Coexistence of FMF with SS is rare ${ }^{5}$, a especially use of azathioprine (AZA) in the treatment of resistant-FMF is yet controversial ${ }^{6,7}$. We aimed to share the post-treatment recovery of a colchicineresistant patient diagnosed with FMF and SS comorbiding vasculitis treated with AZA.

\section{CASE REPORT}

32 years old 10 years since the FMF (M694V homozygous) female patient diagnosed and colchicine twice a day, rash on each, legs, tibia and ankle around the front face, fatigue and joint pain was admitted (Figure 1). Detailed questioning of the patient, the frequency of attacks increased, not decreased frequency and severity of attacks as before with colchicine, were dryness of the mouth and eyes. The patient's saliva test $0.5 \mathrm{~mL} / 15 \mathrm{~min}$, Schirmer test, the right eye was $2 \mathrm{~mm} / 5$ $\mathrm{min}$ in the left eye $3 \mathrm{~mm} / 5 \mathrm{~min}$ respectively. After obtaining approval from the patient, minor salivary gland biopsy was performed on the right lower lip. Biopsy was reported as chronic autoimmune sialoadenitis and skin biopsy was consistent with vasculitis. During admission, CRP: 17 $\mathrm{mg} / \mathrm{dL}$, ESR: $98 \mathrm{~mm} / \mathrm{h}$, fibrinogen: 389 (200-400) mg/dL. Autoantibodies, ANA $(+)$, anti-SS-A (+++) positive, anti-SS-B $(++)$, anti-dsDNA and including anti-Sm other ENA panel was negative. RF (-), anti-CCP (-), and HBV (-), HCV (-) and HIV (-), C3, N, C4, N. Urine protein: $61.13 \mathrm{mg} / 24$ hours. To The patient based on the American-European Consensus Group criteria, were diagnosed with Sjögren's Syndrome. In addition to initial treatment with colchicine, methylprednisolone $16 \mathrm{mg} /$ day, hydroxychloroquine sul- fate, $2 \times 200 \mathrm{mg} /$ day and AZA 2x50 mg/day for vasculitis was started. In the second week of treatment, the patient's skin lesions significantly decreased and AZA dose $3 \times 50 \mathrm{mg} /$ day increased. Before this treatment, she had FMF attacks two to three times in a month (even though maximum $3 \mathrm{mg} /$ day dose of colchicine). The steroid dose was decreased slowly. At six months of the treatment with colchicine 2x1/day, AZA 3x50 mg/day, and HCQ, there was no attack due to FMF.

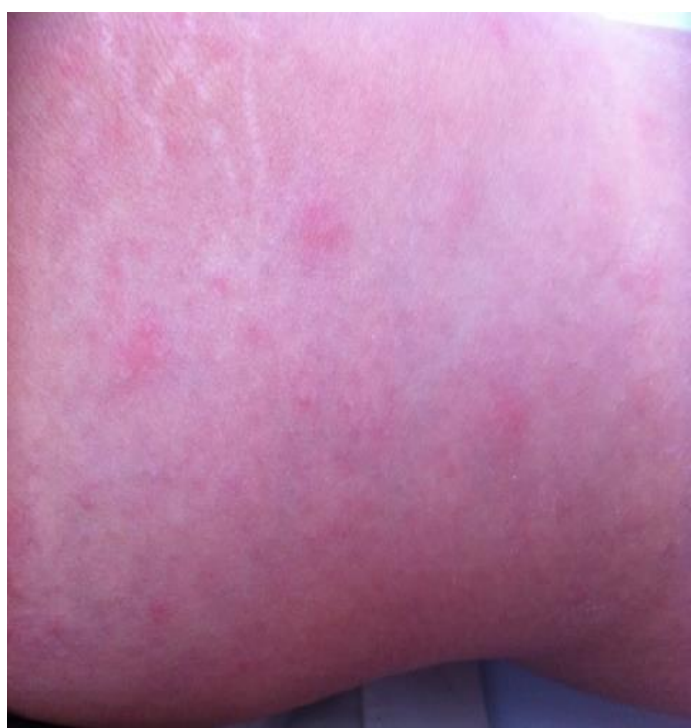

Figure 1: Vasculitic rash on the skin of the patient's left front leg.

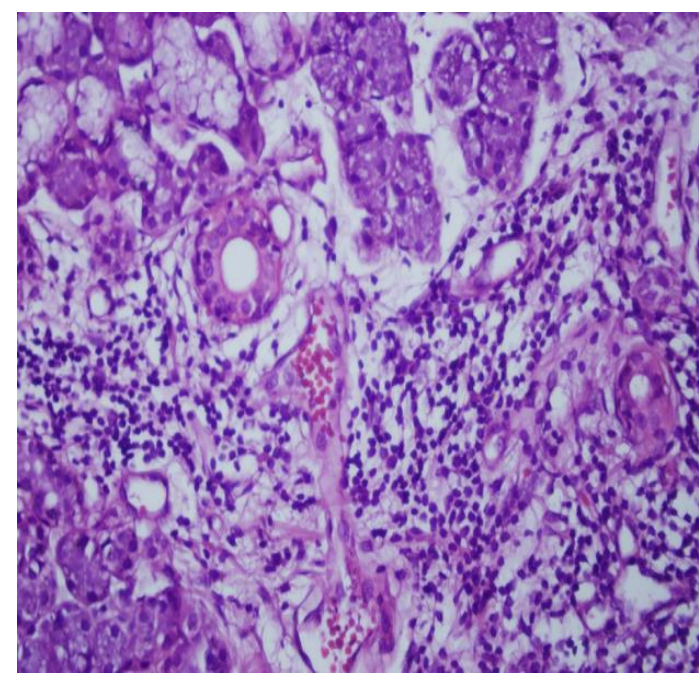

Figure 2: Numerous lymphocytes in the patient with chronic sialadenitis (Hematoxylin Eosin-HE-x400). 


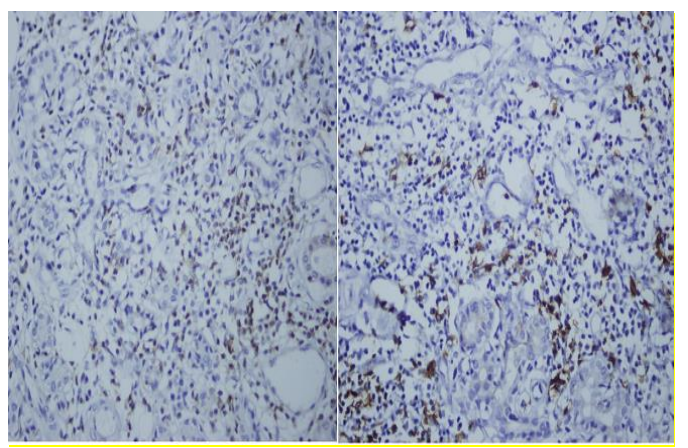

Figure 3: CD3 and CD20 stains highlight the numerous $B$ and $T$ lymphocytes in a minor salivary gland (Right CD3 stain $x 400$, Left CD20 stain $\times 400$ ).

\section{DISCUSSION}

As we know, coexistence of FMF with SS has been rarely reported in the literature ${ }^{5}$. Although SS is known as an autoimmune rheumatic disease, FMF is an autoinflammatory, autosomal recessive inherited disease. MEFV gene mutations placing an important role in the FMF pathogenesis can cause different FMF phenotypes and may interfere with other rheumatic diseases such as SS as well ${ }^{8,12}$.

Vasculitis can be identified during the course of FMF. In particular, it can be seen with findings in the form of PAN, HSP, Behçet's disease and prolonged febrile myalgia. But, our case has been diagnosed as FMF 10 years ago, and also met the classification criteria of SS with objective and subjective findings. We have added AZA to treatment in order to control vasculitic skin lesions and achieved a significant response to FMF attacks with AZA whereas there was no reduction in severity and frequency of attacks with colchicine. The effect of steroid therapy was shown in FMF, especially in prolonged febrile myalgia and vasculitis like $\mathrm{PAN}^{9}$. However, the place and efficacy of AZA in the treatment of FMF is yet controversial ${ }^{6,7}$.

The efficacy of the AZA was shown in FMF related amyloidosis with nephrotic syndrome in 3 patients ${ }^{6}$. Also, immunosuppressive therapy for FMF were discussed in the literature ${ }^{7}$. Furthermore, a response to AZA was shown in a case of FMF patient who had scleritis and sudden hearing $\operatorname{loss}^{10}$. Nowadays, various drugs are being used in the treatment of colchicine-resistant-FMF. Treatment options, in particular, biologicals acting on interleukin (IL)-1 and anti-TNF agents were tested with hopefull result. Among these anakinra is an outstanding one, however it may have a notable adverse-effect profile like other biological agents and difficulty of subcutaneus application every day. Likewise other biological agents, such as anti-TNFs such as anti-TNFs acting through their molecular aspects, and interaction with nuclear factor (NF)-kB indirectly have been tested as effective treatment options ${ }^{14}$. Antiinterleukin-6 monoclonal antibody (tocilizumab) therapy has also been showed that it may be a therapeutic choice in FMF patients with amyloidosis ${ }^{15}$. Unfortunately all these biological agents require off-label use and quite expensive. A 52-year-old colchicine-resistant patient with renal transplantation due to secondary amyloidosis responded to anakinra ${ }^{11}$. Nevertheless, anakinra is a biological agent and might have advers-effect profile similar to other biological agents, difficulty of application (subcutaneous) every day and requires offlabel use and can not be obtained at all times may be drawbacks of anakinra. There is no such problems for AZA which can be obtained easily at all times. Used orally and if necessary it can even be used during pregnancy with important safety profile advantages. Low response or nonresponse can be seen with colchicine approximately in $10-15 \%$ of patients with FMF and increased risk of amyloidosis in patients who remain untreated for a long time $^{12,13}$.

The consensus in the treatment of resistantFMF is controversial yet. Herein, we have seen significant improvement with treatment of AZA in the findings of FMF, in a patient with resistant-FMF and secondary vasculitis due to SS. Long-term and multicentered studies with large sample size are necessary for efficacy of AZA in the treatment of FMF.

\section{REFERENCES}

1. Vitali C, Bombardieri S, Jonsson R. Classification criteria for Sjögren's syndrome: A revised version of the European criteria proposed by the AmericanEuropean Consensus Group. Ann 
Rheum Dis 2002; 61: 544-58.

2. Fox RI. Sjögren's syndrome. Lancet 2005; 366: 321-31.

3. Ramos-Casals M, Tzioufas AG, Font J. Primary Sjögren's syndrome new clinical and therapeutic concepts. Ann Rheum Dis 2005; 64: 347-54.

4. Ben-Chetrit E, Levy M. Familial Mediterranean fever. Lancet 1998; 351: 659-64.

5. Tanaka M, Migita K, Miyashita T, Maeda Y, Nakamura M, Komori A, Ishibashi H, Eguchi K, Kikuchi M, Hirayama K, Yasunami M. Coexistence of familial Mediterranean fever and Sjögren's syndrome in a Japanese patient. Clin Exp Rheumatol 2007; 25: 792.

6. Sayarlioglu H, Erkoc R, Sayarlioglu M, Dogan E, Soyoral Y. Successful treatment of nephrotic syndrome due to FMF amyloidosis with azathioprine: Report of three Turkish cases. Rheumatol Int 2006; 27: 197-9.

7. Korkmaz C. Immunosuppressive treatment of AA amyloidosis of familial Mediterranean fever. Clin Exp Rheumatol 2005; 23: 107-8.

8. Erten S, Erzurum C, Altunoglu A. Three family members with familial Mediteranean fever carrying the M694V mutation showed different clinical presentation. Intern Med 2012; 51: 1765-8.

9. Aksu K, Keser G. Coexistence of vasculitides with familial Mediteranean fever. Rheumatol Int 2011; 31: 1263-74.

10. Akalın T, Demirag MD, Tezcan ME, Ozturk MA. Scleritis and sudden hearing loss associated with familial Mediterranean fever. Clin Exp Rheumatol 2010; 28: 103-4.

11. Alpay N, Sumnu A, Caliskan Y, Yazici H, Turkmen A, Gul A. Efficacy of anakinra treatment in a patient with colchicine-resistant familial Mediterranean fever. Rheumatol Int 2012; 32: 3277-9.

12. Livneh A, Langevitz P, Zemer D. The changing face of familial Mediterranean fever. Semin Ar- thritis Rheum 1996; 26: 612-27.

13. Cerquaglia C, Diaco M, Nucera G, La Regina M, Montalto M, Manna R. Pharmacological and clinical basis of treatment of familial Mediterranean fever (FMF) with colchicine or analogues: An update. Curr Drug Targets Inflamm Allergy $2005 ; 4: 117-24$.

14. Ozgocmen S, Akgul O. Anti-TNF agents in familial Mediterranean fever: Report of three cases and review of the literature. Mod Rheumatol 2011; 21: 684-90.

15. Fujikawa K, Migita K, Tsukada T, Umeda M, Nonaka F, Kawakami A, Eguchi K. Interleukin-6 targeting therapy in familial Mediterranean fever. Clin Exp Rheumatol 2013; 31: 150-1. 